\title{
A 'snip' in time: what is the best age to circumcise?
}

\author{
Brian J Morris ${ }^{1 *}$, Jake H Waskett ${ }^{2}$, Joya Banerjee ${ }^{3}$, Richard G Wamai ${ }^{4}$, Aaron AR Tobian ${ }^{5}$, Ronald H Gray ${ }^{5}$, \\ Stefan A Bailis ${ }^{6}$, Robert C Bailey ${ }^{7}$, Jeffrey D Klausner ${ }^{8}$, Robin J Willcourt ${ }^{9}$, Daniel T Halperin ${ }^{10}$, Thomas E Wiswell ${ }^{11}$ \\ and Adrian Mindel $^{12}$
}

\begin{abstract}
Background: Circumcision is a common procedure, but regional and societal attitudes differ on whether there is a need for a male to be circumcised and, if so, at what age. This is an important issue for many parents, but also pediatricians, other doctors, policy makers, public health authorities, medical bodies, and males themselves.

Discussion: We show here that infancy is an optimal time for clinical circumcision because an infant's low mobility facilitates the use of local anesthesia, sutures are not required, healing is quick, cosmetic outcome is usually excellent, costs are minimal, and complications are uncommon. The benefits of infant circumcision include prevention of urinary tract infections (a cause of renal scarring), reduction in risk of inflammatory foreskin conditions such as balanoposthitis, foreskin injuries, phimosis and paraphimosis. When the boy later becomes sexually active he has substantial protection against risk of HIV and other viral sexually transmitted infections such as genital herpes and oncogenic human papillomavirus, as well as penile cancer. The risk of cervical cancer in his female partner(s) is also reduced. Circumcision in adolescence or adulthood may evoke a fear of pain, penile damage or reduced sexual pleasure, even though unfounded. Time off work or school will be needed, cost is much greater, as are risks of complications, healing is slower, and stitches or tissue glue must be used.
\end{abstract}

Summary: Infant circumcision is safe, simple, convenient and cost-effective. The available evidence strongly supports infancy as the optimal time for circumcision.

Keywords: Circumcision, Public health, Surgery, Infant health, Adolescent health, Foreskin, Urinary tract infections, Sexually transmitted infections, Penile cancer, Cervical cancer, Dermatology, Psychology

\section{Background}

The English proverb "A stitch in time saves nine" teaches that to avoid a bigger problem later immediate effort is preferable to procrastination. Thus fixing a small hole in a sock with one stitch will avoid the need for nine stitches later when the hole becomes bigger. In the present article we consider whether this applies to medical male circumcision (MC) - referred to colloquially as a "snip".

Worldwide 1 in 3 males are circumcised [1,2], totaling an estimated 1.2 billion [2]. In the USA, medical MC is performed on 1.2 million newborns (56\% of baby boys)

\footnotetext{
* Correspondence: brian.morris@sydney.edu.au

'School of Medical Sciences, University of Sydney, Sydney, NSW 2006, Australia

Full list of author information is available at the end of the article
}

in community hospitals annually $[3,4]$. The true number is higher because some boys are circumcised in ambulatory facilities, a physician's clinic or in a private home. In other developed countries infancy is also the most common time for performing MC, whereas in non-Muslim developing countries MC is usually part of comingof-age ceremonies where risks are usually greater [5]. The largest number of circumcised males are Muslims (approx. 70\% of circumcised males globally) [1].

Circumcision predates human history, with evidence of MC from art forms of the Upper Paleolithic period in Europe (38,000 to 11,000 years BCE) [6]. Rather than arising independently in diverse cultures globally [7], the practice more logically arose prior to the migration of Homo sapiens out of Africa [8]. If it had no survival advantage, it is unlikely that it would have persisted,
C Biomed Central

() 2012 Morris et al; licensee BioMed Central Ltd. This is an Open Access article distributed under the terms of the Creative Commons Attribution License (http://creativecommons.org/licenses/by/2.0), which permits unrestricted use, distribution, and reproduction in any medium, provided the original work is properly cited. 
and, as hypothesized by Cox \& Morris, subsequent cessation of $M C$ in some populations was perhaps a result of behavioral changes caused by environmental stressors or new religious philosophies such as Hinduism and Buddhism [8]. Such factors could explain why circumcision is relatively low in European, South and Central America, southern Africa, and non-Muslim Asian countries.

The awareness during Victorian times of a wide array of medical benefits from $\mathrm{MC}$, including prevention of syphilis and better hygiene, led to a rise in its popularity in Anglo-Saxon populations in the $19^{\text {th }}$ century $[7,9]$, continuing today in the USA in particular, where the majority of infant boys are circumcised $[3,4]$. In the UK circumcision is more common in the wealthier upperclasses, marking the fact that a doctor attended the birth rather than a mid-wife.

The advent of the AIDS epidemic in the 1980s refocused interest on $\mathrm{MC}$ as a means of prevention of not just HIV, but other sexually transmitted infections (STIs) and adverse medical conditions. This has led to MC programs in high-HIV prevalence settings of subSaharan Africa focused on men for more immediate reductions in HIV incidence, but considerable interest has also been given to encouraging infant $\mathrm{MC}$ for longer-term gains $[10,11]$. There have as well been recent calls for the promotion of infant MC in the USA $[12,13]$, the UK [14], Australia [15] and sub-Saharan Africa [16,17].

Despite the advantages of $\mathrm{MC}$, few studies have directly compared the relative merits of $\mathrm{MC}$ at different ages. Here we present our findings after reviewing the literature, and document the relative pros and cons of infant $\mathrm{MC}$ versus $\mathrm{MC}$ in later childhood, adolescence or adulthood ("later circumcision"). We compare medical and surgical issues for infant versus later $\mathrm{MC}$, attitudes and barriers, ethical issues, as well as cost-effectiveness. Our analysis has relevance to all countries, both developed and developing. Nevertheless, it should be recognized that a decision about circumcision is subject to varying considerations depending on the particular social and cultural context involved.

\section{Discussion}

\section{Is infancy the best time medically?}

Although an abundance of evidence exists about the benefits of MC $[9,12,13,18]$, it is reasonable to ask whether these dictate infant $\mathrm{MC}$ rather than $\mathrm{MC}$ later in life when a boy can make up his own mind $[19,20]$. Some of the advantages of MC in infancy were featured in a report arising from an expert consultation conducted by the US Centers for Disease Control and Prevention (CDC) in 2007 [13]. Here we discuss several compelling reasons for infancy being the optimum time for MC.

An immediate medical benefit is the greatly reduced risk of a urinary tract infection (UTI), which is higher in infancy than any other year of life, and 10 times greater if the infant male is uncircumcised [21-26]. UTIs are common in uncircumcised infant boys [22-26] and cause severe pain. UTI as a cause of a fever at this age is often undiagnosed $[27,28]$. Bacteriuria in febrile boys presenting at hospital emergency departments occurs in $36 \%$ of uncircumcised boys, pointing to a UTI as the likely cause of fever, compared with only $1.6 \%$ of boys who are circumcised [29]. Antibiotic resistance in pathogenic bacteria under the foreskin is a growing problem [30]. The younger the infant, the more likely and severe the UTI will be, and the greater the risk of sepsis and death [31]. In the still-growing pediatric kidney [26,32] a UTI can result in permanent kidney damage in $34-86 \%$ of cases $[33,34]$, thus exposing the boy to serious, life-threatening conditions later in life [26], including end-stage renal disease in $10 \%$ of cases [35]. In men, risk of UTI is over 5fold higher if they are uncircumcised [36]. Thus infant $\mathrm{MC}$ offers protection against UTI over the lifetime.

Infant MC also offers immediate protection against inflammatory penile skin conditions such as balanitis, posthitis and balanoposthitis that are usually caused by Candida spp. [37]. Balanitis affected 5.9\% of uncircumcised boys in one study [38] and 14\% in another [39]. In male dermatology patients, balanitis was present in $13 \%$ of those who were uncircumcised compared to $2.3 \%$ of the circumcised [40]. After reviewing relevant studies [38-46] we conducted a meta-analysis to determine the level of protection against balanitis. This yielded an OR of 0.32 (95\% CI 0.20-0.52) (Figure 1). Balanoposthitis was a cause of $26 \%$ of cases of acquired phimosis [47], in which the foreskin orifice is so narrow that the foreskin cannot be retracted. Lichen sclerosis, a chronic inflammatory dermatosis that results in white plaques and epidermal atrophy, is a disease of the uncircumcised male. It occurs in $35 \%$ [48] to 55\% [49] of uncircumcised men with type 2 diabetes and peaks in the $30 \mathrm{~s}$ [50]. Although most effectively cured by MC [50], it would be preferable to prevent it by MC in infancy. Delaying circumcision therefore results in greater exposure of the male to risk of penile inflammation.

All boys are born with phimosis. This resolves by about age 3 in all but approximately $10 \%$ of males, who as a result experience problems with micturition, ballooning of the foreskin, and painful difficulties with erections (see review [9]). Paraphimosis can similarly be prevented by infant $\mathrm{MC}$.

Circumcision in infancy also means that by the time the male becomes sexually active, he has partial 


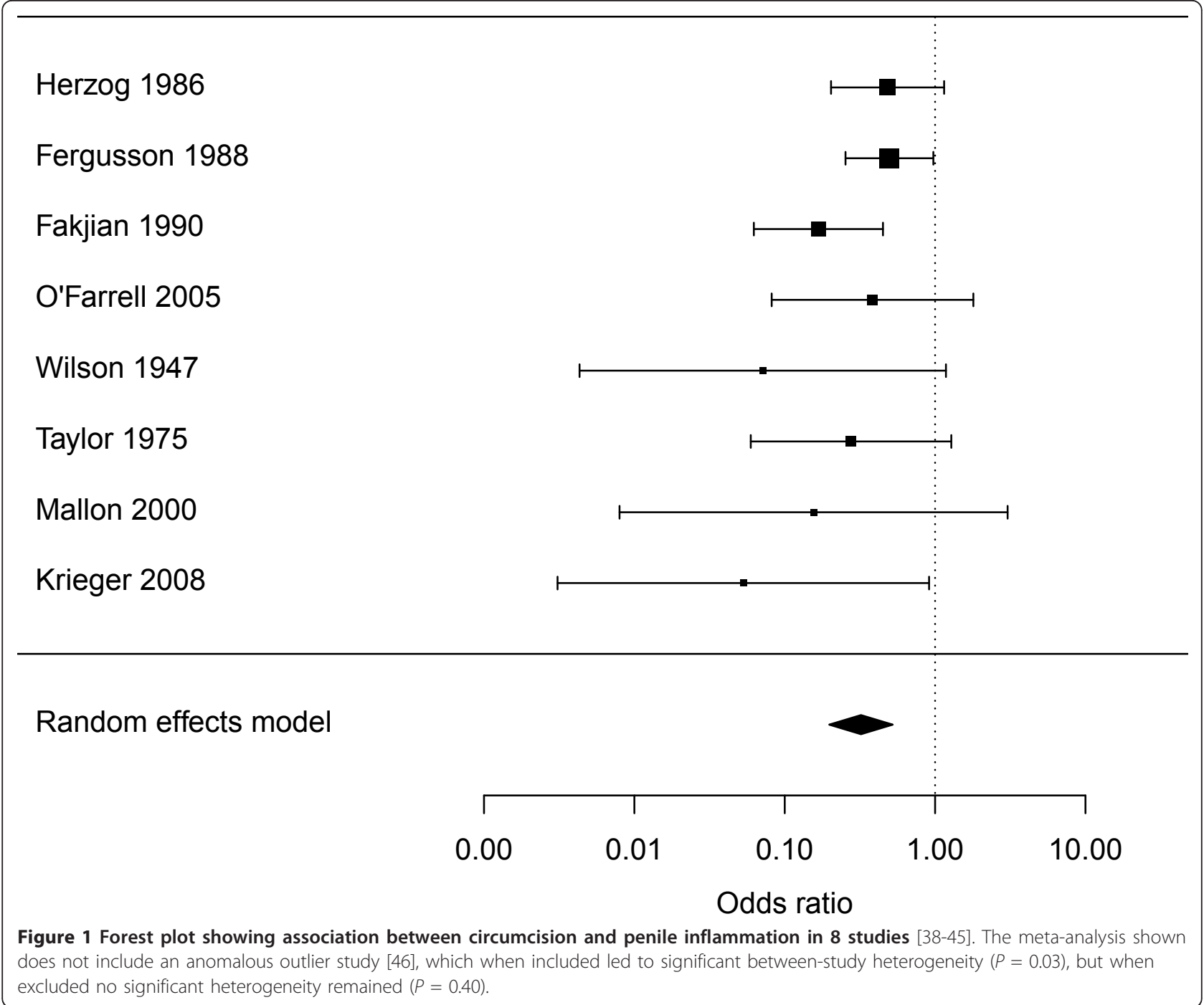

protection against those STIs known to be more prevalent in uncircumcised men $[9,12,18,51,52]$. Meta-analyses of observational studies show MC protects against oncogenic human papillomavirus (HPV) [53,54], genital herpes (HSV-2) [51], syphilis [51] and HIV [55]. The protective effect demonstrated by meta-analyses of the observational data $[51,55]$ has, with the curious exception of syphilis, been reinforced by randomized controlled trials (RCTs) [55-61]). The trials also demonstrated increased efficacy to prevent HIV infection the longer the follow-up period after surgery. The protective effect is greater when $\mathrm{MC}$ is performed prior to sexual debut [51]. In men who have sex with men (MSM), while MC offers little protection against STIs acquired from receptive anal intercourse, MC does appear to protect men who are insertive-only, and to a similar degree as for vaginal heterosexual intercourse [62-64].
If the male is circumcised, his reduced vulnerability to carriage of several STIs means his female partner is less likely to become infected. The female partners of circumcised men are at reduced risk of HPV infection, the main cause of cervical cancer [53,65-67], as well as Trichomonas vaginalis [68] and bacterial vaginosis $[68,69]$. While RCT data were not as clear, observational studies have indicated that MC reduces female HSV-2 [70], Chlamydia trachomatis [71], and HIV [72-74].

MC timing has the same implications for all STIs prevented by MC. If a male becomes sexually active before he is circumcised, he is exposed to a period of increased risk of infection from several STIs. The length of this period varies according to the age at which circumcision is eventually performed. In countries with a high prevalence of STIs, the risk of infection before a male undergoes adult MC may be considerable. HPV and HSV-2 are an epidemic in virtually all countries worldwide 
[75,76]. Importantly, if a male has been circumcised in infancy or childhood, preceding sexual debut, the issue of infection with an STI during the post-MC healing period does not arise.

The risk of penile cancer is very much higher if a man is uncircumcised [54,77]. Many of the conditions above predispose to penile cancer. For example, meta-analyses found phimosis increases risk of penile cancer 12 -fold (8 studies), balanitis 3.8-fold (4 studies) and smegma 3.0fold (4 studies) [54]. These conditions are more common in or restricted to uncircumcised men. At least half of all penile cancers contain high-risk HPV types [78,79] and these can be an important predisposing factor [54]. A meta-analysis [53,54] and data from RCTs [60,80-85] have shown that MC protects against HPV infection. A very conservative meta-analysis noted that there were two-thirds fewer penile cancer cases in men circumcised in childhood [77]. It found the protective effect of $\mathrm{MC}$ may be greater for invasive than in situ penile cancer [77]. Because of lead-time bias and earlier diagnosis in a circumcised man, it was stated that the analysis was likely to have under-estimated the true protective effect of circumcision [77]. An association found between adult $\mathrm{MC}$ and penile cancer could be due to the fact that $\mathrm{MC}$ when performed in adulthood is frequently to remove cancerous lesions or to treat conditions such as phimosis and recurring balanoposthitis that themselves are associated with predisposition to penile cancer. Therefore the association does not necessarily imply that delaying $\mathrm{MC}$ to adulthood increases the risk of penile cancer.

There is also some evidence that MC protects against prostate cancer, a malignancy associated with a history of STIs (see reviews $[9,54,86]$ ).

Arguments that benefits and risks of MC are evenly matched are not supported by an analysis of the frequency of each, as shown in Table 1, which also indicates grade of quality of the evidence [87]. Even though $\mathrm{MC}$ in adults still provides many benefits, and is currently a crucial intervention in the high-HIV-prevalence epidemics of sub-Saharan Africa, where many men are at considerable risk of acquiring HIV, when considering all of the conditions $\mathrm{MC}$ protects against, the benefits of performing this procedure in infancy predominate over later circumcision (Table 2). When aggregating the frequency of each condition that is higher in uncircumcised males, it has been calculated that as many as half of uncircumcised males will, over their lifetime, require medical attention for at least one of these conditions (Table 1). Thus immediate, as well as assured lifetime protection against a range of adverse medical conditions and infections supports infancy as the optimum time to perform circumcision.
While the medical evidence supports infancy as being the optimum time to circumcise, it is recognized that instituting infant circumcision might present a challenge to individuals in cultures in which circumcision is an important part of coming-of-age ceremonies or that are traditionally opposed to circumcision, particularly in countries in which circumcision is a mark of religious affiliation (e.g., Hindu versus Muslim).

\section{Is infancy the best time surgically?}

Evidence clearly shows that circumcision in infancy carries fewer risks of complications than circumcisions performed in childhood or later in life. In infancy, surgical complications for large published series range from $0.2 \%$ to $0.6 \%[23,88-90]$. Higher rates of $2-10 \%$ have been reported in much older and smaller studies [91-93]. A recent systematic review found a median complication frequency of $1.5 \%$ among studies of neonatal or infant circumcision, compared to $6 \%$ among studies of children aged one year or older [94]. Almost all of such complications are minor and can be easily - and completely treated. In both infants and older children, severe complications (as compared to mild complications) were rare, with a median frequency close to zero [94].

While excluded from systematic review, the frequency of complications among adult MC patients was noted to be higher than the frequency of complications from $\mathrm{MC}$ in children older than 1 year [94]. In the large RCTs of adult MC, complications were seen in 1.7-3.8\%; these were virtually all mild or moderate and were effectively treated [56-58] (Table 3).

Another issue is a fear of complications - whether real or imagined - when circumcision is performed later. Such fears can be a significant barrier to uptake of adult MC. In a US study, 59\% of men expressed worries about risks of bleeding and infections [95]. A study in China found that $12.5 \%$ of men were concerned about infection [96]. Education about the actual low frequency of complications is thus necessary to allay such fears.

Other desirable features of infant MC are the surgical ease of performing a circumcision on an immobile newborn, the speed of the operation, absence of any need to use sutures, quick healing, and good cosmetic outcome $[97,98]$. Further information is provided in an extensive recent review of instrumentation and techniques for infant and later circumcision [99].

When the frequency and severity of complications from the procedure itself are compared with the frequency and severity of medical conditions, including deaths, that can result from not circumcising, the evidence strongly favors the argument for MC in infancy [9] (Table 1). Nevertheless, circumcision later is far better than no circumcision at all. 
Table 1 A comprehensive risk-benefit analysis of infant MC

\begin{tabular}{|c|c|c|c|}
\hline \multicolumn{4}{|l|}{ Risks from not circumcising } \\
\hline & & Fold increase & $N N T^{\dagger}$ \\
\hline Urinary tract infection (infants) & $1++$ & 10 & 50 \\
\hline Urinary tract infections (lifetime) & $2+$ & 5 & 4 \\
\hline Pyelonephritis (infants) & $2+$ & 10 & 100 \\
\hline - with concurrent bacteraemia & $2+$ & 200 & 1000 \\
\hline - childhood hypertension & 2 & - & 1500 \\
\hline - end-stage renal disease (lifetime) & $2+$ & - & 500 \\
\hline Candidiasis & 2 & 2 & 10 \\
\hline Prostate cancer & 2 & $1.5-2$ & 6 \\
\hline Balanitis & $2++$ & 3 & 10 \\
\hline Phimosis & $1++$ & infinite & 10 \\
\hline High-risk HPV & $1++$ & 3 & 2 \\
\hline Genital herpes (HSV-2) & $1+$ & 1.35 & \\
\hline Syphilis & $1+$ & 3 & 200 \\
\hline HIV infection & $1++$ & $3-8$ & 1000 \\
\hline Penile cancer & $1++$ & $>20$ & 1000 \\
\hline \multicolumn{4}{|l|}{ In female partner: } \\
\hline Cervical cancer & $1++$ & 4 & - \\
\hline Chlamydia & $2+$ & 4 & - \\
\hline HSV-2 & $2+$ & 2 & - \\
\hline Bacterial vaginosis & $1+$ & 2 & - \\
\hline
\end{tabular}

Thus risk in an uncircumcised male of developing a condition requiring medical attention over their lifetime $=1$ in 2

Risk associated with medical MC in infancy

\section{Condition}

Local bruising at site of injection of local anesthetic (if dorsal penile nerve block used)

Infection, local

Infection, systemic

Excessive bleeding

Need for repeat surgery (if skin bridges or too little prepuce removed)

Loss of penis

Death

Loss of penile sensitivity

Thus risk of an easily-treatable condition $=1$ in 500 and of a true complication $=1$ in 5000

$\begin{array}{lll}\text { Fold increase }_{0.25^{*}} & & {\underline{N N H^{+\dagger}}}^{+\dagger} \\ 0.002 & & 600 \\ 0.0002 & & 4000 \\ 0.001 & & 1000 \\ 0.001 & & 1000 \\ \text { close to 0 } & & 1 \text { million } \\ \text { close to 0 } & & \text { Over 1 million } \\ \text { Low } & & \text { High }\end{array}$

*As per Scottish Intercollegiate Guidelines Network (SIGN) grading system for evidence-based guidelines [87], which ranges from 1++ (highest) to 4 (lowest). Values shown are based on statistics for USA (for source data see review [18] and references cited in the present article) Abbreviations:

${ }^{\dagger} N N T$ number needed to treat - i.e., approximate number of males who need to be circumcised to prevent one case of each condition associated with lack of circumcision.

${ }^{+\dagger} \mathrm{NNH}$ number needed to harm, i.e., approximate number of males that need to be circumcised to see one of each particular (mostly minor) adverse effect. * The minor bruising (from this method only) disappears naturally without any need for medical intervention, so is not included in overall calculation of easily-treatable risks

Table 2 Approximate figures for benefits of circumcision in infancy versus circumcision later

\begin{tabular}{llll}
\hline Condition & Infancy & $\frac{\text { Later }}{5 \times}$ & Critical age for maximum benefit \\
\cline { 2 - 3 } UTI & $10 \times$ & 5 birth, highest risk in $1^{\text {st }}$ year of life \\
Balanitis & 5 -infinity & $3 \times$ & birth \\
Hygiene & $\mathrm{n} / \mathrm{a}$ & $\mathrm{n} / \mathrm{a}$ & birth, higher risk after onset of sexual activity \\
HIV & $3-8 \times$ & $3-8 \times$ & birth \\
HPV & $2 \times$ & $2 \times$ & onset of sexual activity \\
HSV-2 & $1.3 \times$ & $1.3 \times$ & onset of sexual activity \\
Thrush & $2 \times$ & $2 \times$ & onset of sexual activity \\
Penile cancer & $3-22 \times$ & less & onset of sexual activity \\
\hline
\end{tabular}

See main text for references to each condition 


\begin{tabular}{|c|c|c|c|}
\hline Condition & South Africa & Kenya & Uganda \\
\hline Bleeding post-op & $0.6 \%$ & $0.4 \%$ & $0.08 \%$ \\
\hline Infection & $0.2 \%$ & $0.4 \%$ & $0.04 \%$ \\
\hline Wound disruption & $0 \%$ & $0.3 \%$ & $0.04 \%$ \\
\hline Delayed healing & $0.1 \%$ & $0.2 \%$ & $-\dagger$ \\
\hline Swelling or hematoma & $0.6 \%$ & $0.1 \%$ & - \\
\hline Severe pain & $0.8 \%$ & $0 \% *$ & - \\
\hline Appearance problem & $0.6 \%$ & $0 \%$ & - \\
\hline Damage to the penis & $0.3 \%$ & $0 \%$ & - \\
\hline Too much skin removed & $0 \%$ & $0 \%$ & - \\
\hline Too little skin removed & $0.3 \%$ & $0 \%$ & - \\
\hline Anesthesia-related event & $0.06 \%$ & $0.1 \%$ & - \\
\hline Problem urinating & $0 \%$ & $0 \%$ & - \\
\hline Other & $0.3 \%$ & $0.4 \%$ & - \\
\hline Death & $0 \%$ & $0 \%$ & - \\
\hline
\end{tabular}

Refs: [56-58], respectively

${ }^{*}$ At the 3 -day post-operative visit pain was zero in $48 \%$ of men, mild in $52 \%$ and severe in none

tDashes indicate that the item was not reported in the publication

\section{Parental acceptability of MC in infancy}

Despite infancy having a favorable risk-benefit ratio for $\mathrm{MC}$, parents must make the ultimate decision over whether to circumcise infant sons or not. A survey in the USA found that $88 \%$ of participants were willing to circumcise a son [100]. A review of 13 studies in 9 subSaharan African countries found a median of $81 \%$ (range 70-90\%) of women would choose to circumcise their sons [101]. After an informational session about MC, $74 \%$ of men in the Dominican Republic expressed a willingness to have their sons circumcised [102]. In India, a study of women, $78 \%$ of whom were Hindu (a religious group that does not traditionally circumcise), found that after being informed about risks and benefits, $81 \%$ said they would definitely have their boy(s) circumcised if the procedure were offered in a safe hospital setting, free of charge [103]. Only 1\% said they would definitely not have their boy circumcised [103]. In general, when choosing when it should be carried out, the neonatal period or childhood appears to be more acceptable than MC later.

Unfortunately, in a survey in California, 40\% of parents believed they had not been provided with enough information about $\mathrm{MC}$ to make an informed choice [104]. For parents of boys who were not circumcised, the doctor had not discussed circumcision with them, as opposed to $15 \%$ of parents of boys who were circumcised. Twice as many parents would, in retrospect, have wanted their boy to have been circumcised had they known more. After reading information about MC, 86\% of parents were in favor of neonatal circumcision [105]. Overall, support was higher among parents born in the USA, but lower among Hispanic parents.

The reasons for $\mathrm{MC}$ given by Australian parents include family tradition, improved hygiene and reduced risk of diseases and other conditions that $\mathrm{MC}$ protects against [106]. A study of African-American parents found that $96 \%$ strongly believed pediatric circumcision to be healthy, and 73\% considered it essential [107]. Interestingly, the study found that it was the mothers who most often made the final decision. This demonstrates the need to engage and educate mothers and pregnant women about MC for their infant boys.

\section{Acceptability of adult MC}

MC does have benefits at later ages, but a man must be willing to avail himself of these by getting circumcised. It is therefore important to examine the acceptability of MC by adult males. In the USA, only $13 \%$ of uncircumcised heterosexual men indicated that they would be willing to become circumcised to lower their risk of HIV [108]. In sub-Saharan Africa, however, where HIV is an epidemic, an extensive review of 13 studies found that a median of $65 \%$ (range $29-87 \%$ ) of heterosexual men were willing to be circumcised [101]. Men and women in a Kenyan study exhibited a good understanding of the need to maintain safe sexual practices [109]. In India, of 467 uncircumcised heterosexual men in a high-HIV prevalence region, 93\% agreed that men should consider MC for HIV prevention, and 58\% would accept free medical MC [110]. Facilitators of acceptability included improved penile hygiene (97\%), reduced HIV/STIs (91\%), lower risk of penile cancer (90\%) and of cervical cancer in their female partner (86\%) [110]. In Kenya, perceived improvement in sexual pleasure was a facilitator $[109,111]$. In the Dominican Republic willingness was only $29 \%$ initially, but after an information session explaining the risks and benefits of the procedure, this figure increased to $67 \%$ [102]. Acceptability in Thailand was $14 \%$, rising to $25 \%$ after an information session [112]. In a Chinese study, 39\% were willing to be circumcised to protect themselves from infection, and $46 \%$ would consider it to protect their partner as well [113]. In other samples of mostly heterosexual Chinese men, $41 \%$ were willing to be circumcised in one study [114] and 25\% in another [115].

In studies of MSM, a US study found that $53 \%$ of participants were willing to be circumcised in one survey [95], whereas another, conducted in San Francisco, found $28 \%$ of the uncircumcised were willing to get circumcised if there was evidence of efficacy, but only $0.9 \%$ of those for whom MC would be a relevant intervention (mostly those who engaged in insertive anal intercourse 
not using condoms) were willing [116]. In Scotland, only $14 \%$ of MSM indicated their willingness to take part in a circumcision trial [117]. One study in China found 43\% of MSM were willing to be circumcised [96], and in another, $8 \%$ were willing initially, but this rose to $31 \%$ after an information session [118]. The lower rates of acceptability among MSM compared to heterosexual men could be due to the fact that recent studies of MC have not shown a benefit for most MSM in protection against HIV $[63,119]$. However, these studies included men who were both receptive and insertive anal sex partners, and MC only offers protective benefits for MSM who are mostly or exclusively insertive $[63,119]$.

Even if a man is willing to be circumcised this does not mean he will end up having the procedure done. On the other hand, a lack of willingness to be circumcised should not be interpreted as a preference to be uncircumcised. This is because a large number of obstacles have been documented, such as fear of pain or complications, embarrassment, inconvenience and cost. The obstacles are discussed in the following sections. It is reasonable to suppose that, if these barriers could be addressed through the provision of correct information and financial assistance, the fraction of men willing to be circumcised would increase significantly. Better education of parents before or soon after their baby is born about actual risks should, by helping to ensure a circumcision in infancy, avoid later deliberations and barriers to circumcision in adolescence and adulthood.

\section{Barriers \\ Pain}

Since not all men are willing to be circumcised, even when their infection risk from not doing so may be high, there are clearly barriers to an affirmative decision, particularly in high HIV prevalence settings where MC is being rolled-out to reduce infections.

In a review of 13 acceptability studies of heterosexual men in sub-Saharan Africa, concern about possible pain was "the major barrier" to agreeing to be circumcised [101]. As well as pain, the long healing period, meaning no sex, and MC not being part of the local culture, were other impediments to getting a circumcision [109,111]. In Pune, India 71\% of men expressed this concern [110]. Amongst MSM, fear of pain was a barrier for $62 \%$ of men in the USA [95] and was $47 \%$ for Chinese men [96]. An acceptability study among African-American parents found that despite high (88\%) perception of pain in their child, 73\% strongly believed that MC was necessary [107].

In practice, the pain associated with medical MC is far less than men anticipate, and many are not aware that local anesthesia is recommended. In the large RCTs, severe pain was reported in only $0.8 \%$ of 1,568 participants in the South African trial [56], 0.3\% of 2,326 HIV-negative men and $0.2 \%$ of $420 \mathrm{HIV}$ positive men in the Ugandan trial [120], and in the Kenyan trial, of 1,334 men, "very mild" pain was reported in $52 \%$ at postoperative day 3 and $11 \%$ at day 8 , with none of the men reporting pain more severe than "very mild" [57]. In a small trial of the "Shang Ring" device used to circumcise 40 men, pain scores (graded from $0=$ no pain to $10=$ worst possible pain) averaged 3.5 during erections [121]. Since erections would place the most tension on the wound during healing, erections likely contribute maximally to pain scores.

It is instructive to consider here the issue of pain associated with an infant circumcision. In infancy, local anesthesia is effective in reducing or almost eliminating pain during and after circumcision [122], although gauging the level of pain experienced is more subjective than what can be ascertained from communications by older children or men. Of interest is that neonates exhibit lower pain scores than older infants [123]. Their response to pain in general is less when delivered vaginally than by cesarian section [124]. As an aside, early exposure to noxious or stressful stimuli decreases pain sensitivity and behavior in adult life $[125,126]$. While there may be some short-term memory of pain [127], no credible study has been conducted into long-term memory of pain experienced in infancy. Irrespective of such considerations we strongly support a recommendation of adequate pain control as being essential during and after a circumcision at any age.

Thus, although pain is overall minor and should not be seen as a major barrier, the fear of pain for later circumcision does represent a significant barrier.

\section{Cost}

Acceptability studies show cost to be a frequent barrier to adult MC [101], although willingness is higher if costs are borne by others. The barrier of cost, especially for poor families, has not been helped by an unscientific (but successful) lobbying campaign by MC opponents that led 18 states in the USA to eliminate coverage for circumcision by Medicaid, the public insurance program that insured 50.3 million people as of June 2010, or about one of every six Americans [128-130], and that led to a ban on elective MC in public hospitals in all but one state in Australia. While immediate costs to the health system might have been reduced, the longer-term costs for medical need and conditions caused by lack of circumcision can only be greater $[131,132]$.

The cost of a neonatal circumcision is far lower than circumcision later [98]. Cost estimates in the USA for a circumcision are approximate $\$ 165$ [131] to \$257 [133] in infancy, compared with approx. US $\$ 1,800-2,000$ for circumcision in adolescence or adulthood $[131,134]$. Even if the adolescent or adult male wants to be 
circumcised, the cost can be prohibitive. Cost can be reduced by insisting on a local anesthetic, since a general anesthesiologist's fees can be considerable. In developing countries, the cost of a circumcision is typically US\$59 for adults or adolescents, and US\$15 for newborns [11].

Although the costs are greater in developed nations, when represented as a fraction of GDP per capita [135], the figures are comparable between each: $0.4 \%-1.4 \%$ of GDP per capita for neonatal and $4.2 \%-5.4 \%$ for $\mathrm{MC}$ in adolescents or adults. Health interventions are considered highly cost-effective at a threshold below $1 \%$ of GDP per capita [136]. Thus the cost of adult MC represents a significant sum. Affordability of $\mathrm{MC}$ is not helped by the lower earnings typical of younger men. In developing countries, the extreme poverty of many people means any cost is unaffordable by most of the population.

While $\mathrm{MC}$ protects against numerous conditions and infections, in the case of HIV, in locations where HIV prevalence is high and $\mathrm{MC}$ rates are low, increasing adult MC should be regarded as an urgent objective, while increasing infant $\mathrm{MC}$ should be an important objective. In populations where HIV prevalence is still low and $\mathrm{MC}$ rates are low, increasing infant MC should be a priority.

\section{Cost-effectiveness}

In a cost-benefit analysis in the USA it was found that, for a range of medical conditions, "much of the initial cost of neonatal circumcision is eventually recovered when disease and the medical need [in 9.6\% of males] for post-neonatal circumcision are prevented" [131]. This analysis was criticized as being overly conservative [132].

In the case of HIV reduction, modeling in high-prevalence settings such as sub-Saharan Africa has shown that adult MC would be highly cost-effective $[137,138]$. Similarly, neonatal MC was calculated to provide enormous cost savings in populations where HIV prevalence is high [11]. Net cost per HIV infection averted in Rwanda was US\$3,932 for adolescent circumcision and US $\$ 4,949$ for adult circumcision [11]. Reviews of 21 [139] and 5 [140] cost-effectiveness studies found adult $\mathrm{MC}$ to be very cost-effective, the cost per HIV infection averted ranging from US\$174 to US\$2,808 [140]. MC was particularly cost-saving after due consideration of the cost of HIV treatment, treatment cost being estimated as US\$2.3B over 20 years [141].

In low prevalence settings it has been argued that MC is a waste of money as it will have little impact on HIV [142-144]. This may not be true, however, as shown by $\mathrm{CDC}$ calculations that found infant MC to be cost-saving for future HIV prevention in Black and Hispanic males in the USA, although not in non-Hispanic White males, perhaps because the latter have the highest MC rates and much lower HIV prevalence [133].

\section{Cosmetic outcome}

When circumcision is performed in infancy the ability of the inner and outer foreskin layers to adhere to each other means sutures are rarely needed and the scar that results is virtually invisible [98]. Other factors include the more rapid healing at this time of life, contributed by age-associated differences in pro-inflammatory factors that might affect scar formation [145].

In studies on adult MC, both men and their partners preferred the new appearance of the penis post-circumcision [146,147]. In the case of MSM, in a Chinese study, only $2.5 \%$ of men expressed concern about cosmetic outcome [96]. Despite the fact that MC rarely causes permanent disfigurement from scarring when performed properly, the fear of a poor cosmetic outcome is a documented deterrent of acceptability. For example, a study in the South American Andes found that MSM identified the risk of scarring as a significant barrier to MC [148].

\section{Sexual function and activity}

The effect of an infant circumcision on sexual function and activity cannot be determined directly, but can be inferred from studies of men circumcised as adults. Numerous studies show that MC has no adverse effect on sexual function [147,149-152]. This finding is supported by data from the large RCTs in sub-Saharan Africa $[45,153]$ which included more than 10,000 participants. A study in Turkey found no relationship between age of childhood circumcision and overall sexual function in men aged 22-44 [154]. Since all men are circumcised, mostly in childhood, in this Muslim country there was no control group of uncircumcised men to compare with. Of seven areas of sexual function examined (frequency of intercourse, communication, degree of satisfaction, avoidance, sensuality, ejaculatory function and erectile function), the only difference was lower avoidance in those circumcised between the ages of 0-2, compared to the 3-5 and 6-12 age groups [154]. A study of MSM in Sydney reported that later circumcision was associated with erectile dysfunction and premature ejaculation difficulties in some men [155]. Such difficulties were not seen in men who had been circumcised in infancy. In developed countries, most later circumcisions tend to be for treatment of a medical condition and this could offer a partial explanation for the finding. Since men circumcised later were less likely to engage in insertive anal intercourse, psychological effects after MC for medical need, at an age where the male has cognitive awareness of his previous painful penile problems, as 
well as the surgery itself, seemed a probable explanation. In a large Danish study in which circumcision, mostly for medical reasons, accounted for the small proportion of circumcised men surveyed, there were no differences in a range of sexual measures, apart from a statistically questionable [156] difference in ability to reach orgasm during intercourse in a minority of 10 circumcised men [157].

When circumcision is delayed beyond the onset of sexual activity, the impact of a period of abstinence must be considered. Analysis of data from three RCTs found that relatively few men engaged in sexual intercourse within 42 days of circumcision [158]. It has been suggested, not unreasonably, that this period of complete abstinence (from both intercourse and masturbation) is "often daunting and serves as a disincentive for men to undertake the procedure" [159], and the recommended post-surgical abstinence period was found to be a significant barrier to MC uptake in Kenya [111]. Circumcision in infancy, or indeed at any time before puberty, eliminates such an obstacle.

\section{Sexual pleasure}

A range of beliefs exists about the effect of $\mathrm{MC}$ on sexual pleasure and function. A comprehensive review of acceptability studies in sub-Saharan Africa noted that men who were willing to be circumcised considered that MC would not adversely affect sexual pleasure [101]. Subsequent surveys support this, with many men considering that $\mathrm{MC}$ will enhance their sexual performance and satisfaction [111]. However, a belief that MC might reduce their sexual pleasure was the reason $46 \%$ of men in a Dominican Republic study were reluctant to be circumcised [102], as was also the case for $14 \%$ of men in an Indian study [110], and 5.3\% of men in a Chinese survey [96]. In the latter study approximately three times as many men thought circumcision would increase, rather than diminish, their sexual pleasure [96]. In the USA, $18 \%$ of men said they would consider circumcision because it might increase sexual pleasure, this being associated with willingness to be circumcised [95]. In another US study, 35\% of African American parents thought circumcision increases pleasure, although this was not a significant factor in deciding on circumcision for their boys [107].

Fears and anxieties about sexual pleasure appear to be substantial. This may be especially problematic in developed countries with widespread Internet access, as this medium is dominated by anti-circumcision websites, many of which spuriously claim that MC severely harms the sexual experience. This was documented in a survey of 73 Internet sites devoted to MC [160].

Scientific evidence regarding the sexual effects of MC does not substantiate the purported harms to sexual pleasure. The better-quality studies (in terms of sample size, rigor of methodology, accuracy of analysis of findings, and generalizability of results) have found no adverse effect of MC on penile sensitivity [151,161-163], sensation during arousal [164], sexual satisfaction [146,151], premature ejaculation [165], intravaginal ejaculatory latency time $[166,167]$, or erectile function [147,149-152]. Two RCTs found MC does not adversely affect sexual function, sensitivity or satisfaction [45,153], with one of these studies showing that the sexual experience of most men was enhanced after circumcision [45]. Some studies have found that MC reduced the risk of premature ejaculation $[168,169]$.

In several studies, perceptions about partners' sexual pleasure and preferences were also important predictors of willingness to be circumcised [101]. A study of Chinese MSM found that $15 \%$ thought MC would improve the partner's sexual pleasure, while $4 \%$ thought it would decrease it, and 68\% were unsure [96]. In sub-Saharan Africa, 69\% (range 47-79\%) of women preferred circumcision for their partners because of its perceived aesthetic value [101], consistent with credible studies in developed countries $[170,171]$.

Credible studies of the female partners of adult MC patients have found no adverse effect on sexual experience. For example, data from 455 women in a Ugandan RCT indicated no change (57\%) or an improvement $(40 \%)$ in sexual satisfaction after their male partner had been circumcised [172] and a Mexican study found no change in sexual satisfaction, desire, pain during vaginal penetration or orgasm [173]. A study in Sydney of MSM found no overall differences between the circumcised and uncircumcised in participation in insertive or receptive anal intercourse, difficulty in using condoms, or sexual problems such as loss of libido [155]. A survey of US women found $82 \%$ preferred the circumcised penis for fellatio, with only $2 \%$ preferring the uncircumcised penis [170].

The fact that circumcision does not impair - and for many may enhance - a man's sensation and sexual pleasure, should reassure men considering whether to get circumcised [174]. It should also reassure parents who may wonder about this issue when deciding to have their infant son circumcised.

\section{Psychological consequences}

Very few credible studies have examined psychological factors associated with MC.

A study of Californian boys in their early teenage years found that circumcised boys - the majority of whom were circumcised neonatally - were more satisfied with their circumcision status than were uncircumcised boys [175]. A study in Sweden, where MC is uncommon, found no serious psychological disorders amongst 
boys circumcised in childhood, although shyness in the change-room was noted in $7 \%$ [176].

An acceptability study conducted in the Sichuan province of China found $53 \%$ of men were concerned that MC would be "too sensitive and embarrassing" [114]. Concerns were also expressed that men might be mocked for undertaking the surgery.

In India, where $\mathrm{MC}$ is a mark of religious affiliation, $41 \%$ of mostly Hindu men were concerned that MC was not part of their culture, while 30\% were afraid of stigma or rejection [110]. MC has historic implications in India, where Muslim men were targeted for violence based on their circumcision status during the Hindu fundamentalist, anti-Muslim pogroms of 2002 and subsequent riots [177]. It has been suggested that $\mathrm{MC}$ in India might be more acceptable to STI clinic attendees than others [178].

Psychological effects were the probable explanation for findings in MSM that later circumcision, usually performed to treat a medical problem, was associated with lower insertive anal intercourse [155]. As referred to earlier, this is likely because, when older, the male has cognitive awareness of his previous painful penile problems, as well as the surgery itself.

There is some concern about risk-compensation (the tendency to stop using condoms and increase the number of sexual partners) following MC, although in most studies in which men were counseled this was not seen $[179,180]$. It has been suggested that neonatal MC may reduce the chances of a change in behavior due to circumcision status, as the male will not perceive any change in risk compared to what might transpire if the circumcision had taken place at an age when he might be sexually active [181].

While these various psychological problems should be mitigated by making $\mathrm{MC}$ normative in a community, just as with most fears and anxieties, the prospect of such concerns would be largely eliminated if MC were performed in infancy.

\section{Absence from work or school}

Unlike the convenience of circumcising a baby that sleeps most of the time and is a dependent in society, circumcision during productive work or school years will typically require taking time off, although the amount of time off required is typically small. In one study of men circumcised with the Shang Ring device, men took an average of 1.1 days off work; $80 \%$ were back at work by day 2 , with only $20 \%$ requiring more than 2 days, and little disruption to activities or discomfort was reported for the week the ring was in place [121]. Eighteen percent of men in the study reported disruption to their work while the device was present, and 30\% had not resumed routine leisure activities by 7 days. In the large Kenyan RCT, only $4 \%$ of men required 3 days or more before they could return to normal activities [57]. In a study of childhood MC, median times of 5 days to return to normal activity and 7 to return to school have been reported [182]. This may have been because children are usually more active than adults, thus increasing the chances of injury and so prolonging the healing period.

\section{Ethical considerations}

Nowhere is MC illegal. Concern has, however, been expressed by some authors about the ethical implications of circumcising boys who are too young to give consent $[19,20]$. The "autonomy-centered" argument of these authors is that MC should be delayed until the individual can decide for himself. But it has been pointed out that this argument is not consistent with the rationale behind other interventions, such as vaccinations, which are similarly performed before the child is old enough to consent and which carry similar risks of complications [183-185]. The authors of one bioethical analysis concluded that $\mathrm{MC}$ is appropriate for parental discretion [184]. Other bioethicists have argued that $\mathrm{MC}$ in the face of high risk of infection and disease is ethically imperative, as to do otherwise would risk human lives [17] and under such circumstances MC should be regarded as a justifiable public health measure [185]. Given the high infection and disease risk overall to the male and his female partners (Table 1) there would be few populations in the world that would not benefit from MC.

\section{Conclusions}

Infancy presents a "window of opportunity" for circumcision. It is associated with substantially lower costs, lower risk of complications when performed by an experienced operator in a clinical or other appropriate setting, and lower lifetime risk of a variety of adverse conditions and infections [186]. The health benefits include protection against urinary tract infection and thus permanent damage to the still-growing kidney, reduced likelihood of penile inflammation, and elimination of risk of phimosis, which impedes micturition and results in difficult and painful erections in adolescence and adulthood. It also means tearing of the fragile foreskin and frenulum is avoided. Circumcision means an assurance of greatly reduced risk of penile cancer later in life, no smegma, better hygiene, and lower risk of various STIs. These not only include HIV that is an epidemic in some locations, but also oncogenic HPVs and genital herpes that are an epidemic worldwide. In the future female sexual partners of males, infant MC means they too will be at reduced risk of STIs and cervical cancer. 
Some of the arguments against waiting until later to circumcise are:

- Protection against UTIs and damage to the fragile pediatric kidney is lost.

- Infant MC eliminates risk of phimosis and balanitis in childhood and after puberty.

- If circumcision is performed after boys become sexually active benefits associated with STI prevention are delayed.

- The risk of complications is higher for later circumcisions.

- The cost (to the individual or the public purse) is much higher, and often unaffordable, for later circumcision.

- Educational resources for boys to make an informed decision are quite limited.

- Large-scale adolescent circumcision would strain medical resources.

- Boys who later choose circumcision will likely wish it had been performed in infancy.

- Many older boys and men may not want to face an operation even though they wish to be circumcised.

- The momentum amongst major international and American health and medical organizations towards encouraging circumcision, especially in infancy.

Circumcision in infancy avoids any embarrassment of having it done later, as well as anxieties about pain, complications and adverse sexual effects, even though these are minimal or not supported by evidence. It also avoids arguments about whether there might be adverse psychological consequences for MC performed later in childhood. And absence from work or school is avoided.

There are fewer barriers to MC in infancy. The infant is less mobile, so facilitating the use of local anesthesia, the procedure is simpler, healing is quicker, the cosmetic outcome is superior, and cost-effectiveness is high, as is acceptability. The neonatal period should therefore be regarded as the optimal time to perform circumcision. It is viewed as a vital component of public health strategies aimed at realizing high levels of $\mathrm{MC}$ in the population [187]. The procedure should be performed by a trained professional using appropriate local anesthesia in a clean environment. Circumcision outside of such a setting is ill-advised, so explaining why clinical $\mathrm{MC}$ is increasingly being made available in European countries to Muslim families.

We recommend that evidence-based policies be developed regarding the availability of infant MC in all countries worldwide. It has been suggested that policies surrounding neonatal MC should be integrated into existing health systems as part of postnatal care [183], with adolescent and adult MC constituting "catch-up" campaigns that would be phased out over time [11]. This should not detract from the immediate urgent need for safe voluntary adult medical MC services in high-HIV-prevalence regions in particular.

\section{Author details}

${ }^{1}$ School of Medical Sciences, University of Sydney, Sydney, NSW 2006 Australia. ${ }^{2}$ Circumcision Independent Reference and Commentary Service, 157 Stand Lane, Radcliffe, Manchester M26 1JR, UK. ${ }^{3}$ Global Youth Coalition on HIV/AIDS, Pretoria, South Africa. ${ }^{4}$ Department of African-American Studies, Northeastern University, Boston, MA 02115, USA. ${ }^{5}$ Department of Pathology, School of Medicine, Johns Hopkins University, Baltimore, MD 21287, USA.

${ }^{6}$ Research \& Education Association on Circumcision Health Effects, Bloomington, MN 55425, USA. ${ }^{7}$ Division of Epidemiology and Biostatistics, University of Illinois at Chicago, Chicago, IL, USA. ${ }^{8}$ Divisions of AIDS \& Infectious Diseases, University of California, San Francisco, CA 94122, USA. ${ }^{9}$ Pregnancy Advisory Centre, The Queen Elizabeth Hospital, Adelaide, SA 5011, Australia. ${ }^{10}$ Department of Education and Behavior, University of North Carolina School of Public Health, Chapel Hill, NC 27599, USA. ${ }^{11}$ Center for Neonatal Care, Orlando, FL 32804, USA. ${ }^{12}$ Sexually Transmitted Infections Research Centre, Westmead Hospital and University of Sydney, Sydney, NSW 2145, Australia.

\section{Authors' contributions}

BJM and JHW drafted the manuscript. JHW performed the statistical analyses shown in Figure 1. BJM, JHW, JB, RGM, AART, RHG, SAB, RCB, JDK, RJW, DTH, TEW and AM made substantial contributions to successive drafts and thereby to the intellectual content of this article. All authors read and approved the final manuscript.

\section{Competing interests}

The authors declare that they have no competing interests.

Received: 2 September 2011 Accepted: 28 February 2012 Published: 28 February 2012

\section{References}

1. World Health Organization/UNAIDS: Male circumcision: Global trends and determinants of prevalence, safety and acceptability. World Health Organization, Geneva; 2007 [http://whqlibdoc.who.int/publications/2007/ 9789241596169_eng.pdf].

2. Waskett JH: Global circumcision rates. 2011 [http://www.circs.org/index. php/Reviews/Rates/Global].

3. Merrill CT, Nagamine M, Steiner C: Circumcisions Performed in U.S. Community Hospitals, 2005: Statistical Brief \#45. Healthcare Cost and Utilization Project 2008, 1-9[http://www.ncbi.nlm.nih.gov/books/NBK56311/].

4. Healthcare Cost and Utilization Project (HCUP): Statistical Brief \#118. Agency for Healthcare Research and Quality, Rockville, MD; 2011 [http:// www.hcup-us.ahrq.gov/reports/statbriefs/sb118.jsp].

5. Wilcken A, Keil T, Dick B: Traditional male circumcision in eastern and southern Africa: a systematic review of prevalence and complications. Bull World Health Organ 2010, 88:907-914.

6. Angulo JC, García-Díez M: Male genital representation in Paleolithic art: erection and circumcision before history. Urology 2009, 74:10-14.

7. Kaicher DC, Swan KG: A cut above: Circumcision as an ancient status symbol. Urology 2010, 76:18-20.

8. Cox G, Morris BJ: Why circumcision - From pre-history to the 21st century. In Surgical Guide to Circumcision. Edited by: Bolnick DA, Koyle MA, Yosha A. Springer, London; 2012:.

9. Morris BJ: Why circumcision is a biomedical imperative for the 21st century. Bioessays 2007, 29:1147-1158.

10. Hargreave T: Male circumcision: towards a World Health Organisation normative practice in resource limited settings. Asian J Androl 2010, 12:628-638.

11. Binagwaho A, Pegurri E, Muita J, Bertozzi S: Male circumcision at different ages in Rwanda: a cost-effectiveness study. PLoS Med 2010, 7:e1000211.

12. Tobian AA, Gray RH, Quinn TC: Male circumcision for the prevention of acquisition and transmission of sexually transmitted infections: the case for neonatal circumcision. Arch Pediatr Adolesc Med 2010, 164:78-84.

13. Smith DK, Taylor A, Kilmarx PH, Sullivan P, Warner L, Kamb M, Bock N, Kohmescher B, Mastro TD: Male circumcision in the United States for the 
prevention of HIV infection and other adverse health outcomes: Report from a CDC consultation. Public Health Rep 2010, 125(Suppl 1):72-82.

14. Macdonald A, Humphreys J, Jaffe HW: Prevention of HIV transmission in the United Kingdom: what is the role of male circumcision? Sex Transm Infect 2008, 84:158-160.

15. Cooper DA, Wodak AD, Morris BJ: The case for boosting infant male circumcision in the face of rising heterosexual transmission of HIV. Med $J$ Aust 2010, 193:318-319.

16. Weiss HA, Dickson KE, Agot K, Hankins CA: Male circumcision for HIV prevention: current research and programmatic issues. AIDS 2010, 24(Suppl 4):S61-S69.

17. Clark PA, Eisenman J, Szapor S: Mandatory neonatal male circumcision in Sub-Saharan Africa: medical and ethical analysis. Med Sci Monit 2007, 12:205-213.

18. Morris BJ: Circumcision: an evidence-based appraisal - medical, health and sexual (a review with 1,023 references). 2010 [http://www.circinfo. net].

19. Perera CL, Bridgewater FH, Thavaneswaran P, Maddern GJ: Nontherapeutic male circumcision: tackling the difficult issues. J Sex Med 2009, 6:2237-2243

20. MacDonald N: Male circumcision: get the timing right. CMAJ 2011, 183:872.

21. Singh-Grewal D, Macdessi J, Craig J: Circumcision for the prevention of urinary tract infections in boys: a systematic review of randomized trials and observational studies. Arch Dis Child 2005, 90:853-858.

22. Wiswell TE, Smith FR, Bass JW: Decreased incidence of urinary tract infections in circumcised male infants. Pediatrics 1985, 75:901-903.

23. Wiswell TE, Geschke DW: Risks from circumcision during the first month of life compared with those for uncircumcised boys. Pediatrics 1989 83:1011-1015

24. Wiswell TE: Circumcision circumspection. N Engl J Med 1997, 36:1244-1245.

25. Schoen EJ, Colby CJ, Ray GT: Newborn circumcision decreases incidence and costs of urinary tract infections in the first year of life. Pediatrics 2000, 105:789-793.

26. Wiswell TE: The prepuce, urinary tract infections, and the consequences. Pediatrics 2000, 105:8602

27. Zorc JJ, Levine DA, Platt SL, Dayan PS, Macias CG, Krief W, Schor J, Bank D, Shaw KN, Kuppermann N: Clinical and demographic factors associated with urinary tract infection in young febrile infants. Pediatrics 2005, 116:644-648.

28. Shaikh $\mathrm{N}$, Morone NE, Bost JE, Farrell MH: Prevalence of urinary tract infection in childhood: a meta-analysis. Pediatr Infect Dis J 2008, 27:302-308.

29. Hsiao AL, Chen L, Baker MD: Incidence and predictors of serious bacterial infections among 57- to 180-day-old infants. Pediatrics 2006, 117:1695-1701.

30. Ladhani S, Gransden W: Increasing antibiotic resistance among urinary tract isolates. Arch Dis Child 2003, 88:445-445.

31. Schoen EJ: Circumcision for preventing urinary tract infections in boys: North American view. Arch Dis Child 2005, 90:772-773.

32. Shortliffe LM, MCCue JD: Urinary tract infection at the age extremes: pediatrics and geriatrics. Am J Med 2002, 113(Suppl 1A):55-66.

33. Zorc JJ, Kiddoo DA, Shaw KN: Diagnosis and management of pediatric urinary tract infections. Clin Microbiol Rev 2005, 18:417-422.

34. Rushton HG, Majd M: Dimercaptosuccinic acid renal scintigraphy for the evaluation of pyelonephritis and scarring: a review of experimental and clinical studies. J Urol 1992, 148:1726-1732.

35. Jacobson SH, Eklof O, Eriksson CG, Lins LE, Tidgren B, Winberg J: Development of hypertension and uraemia after pyelonephritis in childhood: 27 year follow up. Brit Med J 1989, 16:703-706.

36. Spach DH, Stapleton AE, Stamm WE: Lack of circumcision increases the risk of urinary tract infections in young men. J Am Med Assoc 1992, 267:679-681.

37. Edwards S: Balanitis and balanoposthitis: a review. Genitourin Med 1996, 72:155-159.

38. Herzog LW, Alvarez SR: The frequency of foreskin problems in uncircumcised children. Am J Dis Child 1986, 140:254-256.

39. Fergusson DM, Lawton JM, Shannon FT: Neonatal circumcision and penile problems: an 8-year longitudinal study. Pediatrics 1988, 81:537-541.

40. Fakjian N, Hunter S, Cole GW, Miller J: An argument for circumcision. Prevention of balanitis in the adult. Arch Dermatol 1990, 126:1046-1047.
41. O'Farrell N, Quigley M, Fox P: Association between the intact foreskin and inferior standards of male genital hygiene behaviour: a cross-sectional study. Int J STD AIDS 2005, 16:556-559.

42. Wilson RA: Circumcision and venereal disease. Can Med Ass J 1947, 56:54-56.

43. Taylor PK, Rodin P: Herpes genitalis and circumcision. Brit J Ven Dis 1975, 51:274-277.

44. Mallon E, Hawkins D, Dinneen M, Francis N, Fearfield L, Newson R, Bunker C: Circumcision and genital dermatoses. Arch Dermatol 2000, 136:350-354

45. Krieger JN, Mehta SD, Bailey RC, Agot K, Ndinya-Achola JO, Parker C, Moses S: Adult male circumcision: effects on sexual function and sexual satisfaction in Kisumu, Kenya. J Sex Med 2008, 5:2610-2622.

46. Van Howe RS: Neonatal circumcision and penile inflammation in young boys. Clin Pediatr (Phila) 2007, 46:329-333.

47. Bromage SJ, Crump A, Pearce I: Phimosis as a presenting feature of diabetes. BJU Int 2007, 101:338-340.

48. Kohn F-M, Pflieger-Bruss S, Schill W-B: Penile skin diseases. Andrologia 1999, 31(suppl 1):3-11.

49. Verma $S B$, Wollina $\mathrm{U}$ : Looking through the cracks of diabetic candidal balanoposthitis. Int J Gen Med 2011, 4:511-513.

50. Edmonds EV, Hunt S, Hawkins D, Dinneen M, Francis N, Bunker CB: Clinical parameters in male genital lichen sclerosus: a case series of 329 patients. J Eur Acad Dermatol Venereol 2011

51. Weiss HA, Thomas SL, Munabi SK, Hayes RJ: Male circumcision and risk of syphilis, chancroid, and genital herpes: a systematic review and metaanalysis. Sex Transm Infect 2006, 82:101-109.

52. Morris BJ, Castellsague $X$ : The role of circumcision in the prevention of STIs. In Sexually Transmitted Infections and Sexually Transmitted Diseases. Edited by: Gross GE, Tyring S. Heidelberg: Springer; 2011:715-739.

53. Bosch FX, Albero G, Castellsagué X: Male circumcision, human papillomavirus and cervical cancer: from evidence to intervention. J Fam Plann Reprod Health Care 2009, 35:5-7.

54. Morris BJ, Gray RH, Castellsague X, Bosch FX, Halperin DT, Waskett JH, Hankins CA: The strong protection afforded by circumcision against cancer of the penis. Adv Urol 2011, Article ID 812368(21 pages).

55. Weiss HA, Halperin D, Bailey RC, Hayes RJ, Schmid G, Hankins CA: Male circumcision for HIV prevention: from evidence to action? (Review). AIDS 2008, 22:567-574.

56. Auvert B, Taljaard D, Lagarde E, Sobngwi-Tambekou J, Sitta R, Puren A: Randomized, controlled intervention trial of male circumcision for reduction of HIV infection risk: the ANRS 1265 Trial. PLOS Med 2005, 2(e298):1112-1122.

57. Bailey RC, Moses S, Parker CB, Agot K, Maclean I, Krieger JN, Williams CF, Campbell RT, Ndinya-Achola JO: Male circumcision for HIV prevention in young men in Kisumu, Kenya: a randomised controlled trial. Lancet 2007, 369:643-656.

58. Gray RH, Kigozi G, Serwadda D, Makumbi F, Watya S, Nalugoda F, Kiwanuka N, Moulton LH, Chaudhary MA, Chen MZ, Sewankambo NK, Wabwire-Mangen F, Bacon MC, Williams CF, Opendi P, Reynolds SJ, Laeyendecker O, Quinn TC, Wawer MJ: Male circumcision for HIV prevention in men in Rakai, Uganda: a randomised trial. Lancet 2007, 369:657-666.

59. Siegfried N, Muller M, Deeks JJ, Volmink J: Male circumcision for prevention of heterosexual acquisition of HIV in men. Cochrane Database Syst Rev 2009, 2, CD003362(38pages).

60. Tobian AAR, Serwadda D, Quinn TC, Kigozi G, Gravitt PE, Laeyendecker O, Charvat B, Ssempijja V, Riedesel M, Oliver AE, Nowak RG, Moulton LH, Chen MZ, Reynolds SJ, Wawer MJ, Gray RH: Male circumcision for the prevention of HSV-2 and HPV infections and syphilis. N Engl J Med 2009, 360:1298-1309

61. Tobian AAR, Charvat B, Ssempijja V, Kigozi G, Serwadda D, Makumbi F, Iga B, Laeyendecker O, Riedesel M, Oliver A, Chen MZ, Reynolds SJ, Wawer MJ, Gray RH, Quinn TC: Factors associated with the prevalence and incidence of herpes simplex virus type 2 infection among men in Rakai, Uganda. J Infect Dis 2009, 199:945-949.

62. Templeton DJ, Jin F, Prestage GP, Donovan B, Imrie JC, Kippax SC, Cunningham PH, Kaldor JM, Mindel A, Cunningham AL, Grulich AE: Circumcision and risk of sexually transmissible infections in a community-based cohort of HIV-negative homosexual men in Sydney, Australia. J Infect Dis 2009, 200:1813-1819. 
63. Wiysonge CS, Kongnyuy EJ, Shey M, Muula AS, Navti OB, AkI EA, Lo YR: Male circumcision for prevention of homosexual acquisition of HIV in men. Cochrane Database Syst Rev 2011, 6, CD007496(46pages).

64. Jameson DR, Celum CL, Manhart L, Menza TW, Golden MR: The association between lack of circumcision and HIV, HSV-2, and other sexually transmitted infections among men who have sex with men. Sex Transm Dis 2010, 37:147-152.

65. Castellsague X, Bosch FX, Munoz N, Meijer CJLM, Shah KV, de Sanjose S, Eluf-Neto J, Ngelangel CA, Chichareon S, Smith JS, Herrero R, Franceschi S: Male circumcision, penile human papillomavirus infection, and cervical cancer in female partners. N Engl J Med 2002, 346:1105-1112.

66. Drain PK, Halperin DT, Hughes JP, Klausner JD, Bailey RC: Male circumcision, religion, and infectious diseases: an ecologic analysis of 118 developing countries. BMC Infect Dis 2006, 6, 172(10pages).

67. Wawer MJ, Tobian AAR, Kigozi G, Kong X, Gravitt PE, Serwadda D, Nalugoda F, Makumbi F, Ssempiija V, Sewankambo N, Watya S, Eaton KP, Oliver AE, Chen MZ, Reynonds SJ, Quinn TC, Gray RH: Effect of circumcision of HIV-negative men on transmission of human papillomavirus to HIV-negative women: a randomised trial in Rakai, Uganda. Lancet 2011, 377:209-218.

68. Gray RH, Kigozi G, Serwadda D, Makumbi F, Nalugoda F, Watya S, Moulton L, Chen MZ, Sewankambo NK, Kiwanuka N, Sempijja V, Lutalo T, Kagayii J, Wabwire-Mangen F, Ridzon R, Bacon M, Wawer MJ: The effects of male circumcision on female partners' genital tract symptoms and vaginal infections in a randomized trial in Rakai, Uganda. Am J Obstet Gynecol 2009, 200:e1-e7.

69. Cherpes TL, Hillier SL, Meyn LA, Busch JL, Krohn MA: A delicate balance: risk factors for acquisition of bacterial vaginosis include sexual activity, absence of hydrogen peroxide-producing lactobacilli, black race, and positive herpes simplex virus type 2 serology. Sex Transm Dis 2008, 35:78-83.

70. Cherpes TL, Meyne LA, Krohn MA, Hiller SL: Risk factors for infection with herpes simplex virus type 2: role of smoking, douching, uncircumcised males, and vaginal flora. Sex Transm Dis 2003, 30:405-410.

71. Castellsague X, Peeling RW, Franceschi S, de Sanjose S, Smith JS, Albero G, Diaz M, Herrero R, Munoz N, Bosch FX: Chlamydia trachomati infection in female partners of circumcised and uncircumcised adult men. Am J Epidemiol 2005, 162:907-916.

72. Hallett TB, Alsallaq RA, Baeten JM, Weiss H, Celum C, Gray R, Abu-Raddad L: Will circumcision provide even more protection from HIV to women and men? New estimates of the population impact of circumcision interventions. Sex Transm Infect 2011, 87:88-93.

73. Weiss HA, Hankins CA, Dickson K: Male circumcision and risk of HIV infection in women: a systematic review and meta-analysis. Lancet Infect Dis 2009, 9:669-677.

74. Baeten JM, Donnell D, Kapiga SH, Ronald A, John-Stewart G, Inambao M, Manongi R, Vwalika B, Celum C: Male circumcision and risk of male-tofemale HIV-1 transmission: a multinational prospective study in African HIV-1-serodiscordant couples. AIDS 2010, 24:737-744.

75. Bruni L, Diaz M, Castellsagué X, Ferrer E, Bosch FX, de Sanjosé S: Cervical human papillomavirus prevalence in 5 continents: meta-analysis of 1 million women with normal cytological findings. J Infect Dis 2010, 202:1789-1799.

76. Centers for Disease Control and Prevention: Seroprevalence of herpes simplex virus type 2 among persons aged 14-49 years-United States, 2005-2008. MMWR Morb Mortal Wkly Rep 2010, 59:456-459.

77. Larke NL, Thomas SL, Dos Santos Silva I, Weiss HA: Male circumcision and penile cancer: a systematic review and meta-analysis. Cancer Causes Control 2011, 22:1097-1110.

78. Gross G, Pfister H: Role of human papillomavirus in penile cancer, penile intraepithelial squamous cell neoplasias and in genital warts. Med Microbiol Immunol 2004, 193:35-44.

79. Madsen BS, van den Brule AJ, Jensen HL, Wohlfahrt J, Frisch M: Risk factors for squamous cell carcinoma of the penis-population-based case-control study in Denmark. Cancer Epidemiol Biomarkers Prev 2008, 17:2683-2691.

80. Tobian AAR, Kong X, Gravitt PE, Eaton KP, Kigozi G, Serwadda D, Oliver AE, Nalugoda F, Makumbi F, Chen MZ, Wawer MJ, Quinn TC, Gray RH: Male circumcision and anatomic sites of penile human papillomavirus in Rakai, Uganda. Int J Cancer 2011, 129:2970-2975.

81. Gray RH: Infectious disease: Male circumcision for preventing HPV infection. Nat Rev Urol 2009, 6:298-299.
82. Gray RH, Serwadda D, Kong X, Makumbi F, Kigozi G, Gravitt PE, Watya S, Nalugoda F, Ssempijja V, Tobian AA, Kiwanuka N, Moulton LH, Sewankambo NK, Reynolds SJ, Quinn TC, Iga B, Laeyendecker O, Oliver AE, Wawer MJ: Male circumcision decreases acquisition and increases clearance of high-risk human papillomavirus in HIV-negative men: a randomized trial in Rakai, Uganda. J Infect Dis 2010, 201:1455-1462.

83. Serwadda D, Wawer MJ, Makumbi F, Kong X, Kigozi G, Gravitt P, Watya S, Nalugoda F, Ssempijja V, Tobian AA, Kiwanuka N, Moulton LH, Sewankambo NK, Reynolds SJ, Quinn TC, Oliver AE, Iga B, Laeyendecker O, Gray RH: Circumcision of HIV-infected men: effects on high-risk human papillomavirus infections in a randomized trial in Rakai, Uganda. J Infect Dis 2010, 201:1463-1469.

84. Viscidi RP, Shah KV: Adult male circumcision: will it reduce disease caused by human papillomavirus? J Infect Dis 2010, 201:1447-1449.

85. Auvert B, Sobngwi-Tambekou J, Cutler E, Nieuwoudt M, Lissouba P, Puren A, Taljaard D: Effect of male circumcision on the prevalence of high-risk human papillomavirus in young men: results of a randomized controlled trial conducted in orange farm, South Africa. J Infect Dis 2009, 199:14-19.

86. Morris BJ, Waskett J, Bailis SA: Case number and the financial impact of circumcision in reducing prostate cancer. BJU Int 2007, 100:5-6.

87. Harbour R, Miller J: A new system for grading recommendations in evidence based guidelines. BMJ 2001, 323:334-336.

88. Cilento BGJ, Holmes NM, Canning DA: Plastibell complications revisited. Clin Pediatr 1999, 38:239-242.

89. Christakis DA, Harvey E, Zerr DM, Feudtner C, Wright JA, Connell FA: A trade-off analysis of routine newborn circumcision. Pediatrics 2000, 105:246-249.

90. Ben Chaim J, Livne PM, Binyamini J, Hardak B, Ben-Meir D, Mor Y: Complications of circumcision in Israel: a one year multicenter survey. Isr Med Assoc J 2005, 7:368-370.

91. Frank R: Comment on "Christakis DA et al. A trade-off analysis of routine newborn circumcision. Pediatrics 2000; 105 (Part 3): 246-249". Pediatrics 2000, 106:954

92. Griffiths DM, Atwell JD, Freeman NV: A prospective survey of the indications and morbidity of circumcision in children. Eur Urol 1985, 11:184-187.

93. Kaplan GW: Complications of circumcision. Urol Clin North Am 1983, 10:543-549.

94. Weiss HA, Larke N, Halperin D, Schenker I: Complications of circumcision in male neonates, infants and children: a systematic review. BMC Urol 2010, 10:2, (13pages).

95. Begley EB, Jafa K, Voetsch AC, Heffelfinger JD, Borkowf CB, Sullivan PS: Willingness of men who have sex with men (MSM) in the United States to be circumcised as adults to reduce the risk of HIV infection. PLoS One 2008, 3:e2731.

96. Ruan Y, Qian HZ, Li D, Shi W, Li Q, Liang H, Yang Y, Luo F, Vermund SH, Shao $Y$ : Willingness to be circumcised for preventing HIV among Chinese men who have sex with men. AIDS Patient Care STDS 2009, 23:315-321.

97. Schoen EJ: Male circumcision. In Male Sexual Dysfunction. Pathophysiology and Treatment. Edited by: Kandeel FR, Lue TF, Pryor JL, Swerdloff RS. New York: Informa; 2007:95-107.

98. Schoen EJ: Should newborns be circumcised? Yes. Can Fam Physician 2007, 53:2096-2097.

99. Morris BJ, Eley C: Male circumcision: an appraisal of current instrumentation. In Biomedical Engineering - From Theory to Applications. Volume 14. Edited by: Fazel-Rezai R. InTech, Rijeka, Croatia; 2011:315-354.

100. Gust DA, Kretsinger K, Gaul Z, Pals S, Heffelfinger JD, Begley E, Chen RT, Kilmarx PH: Acceptability of newborn circumcision to prevent HIV infection in the United States. Sex Transm Dis 2011, 52:270-273.

101. Westercamp N, Bailey RC: Acceptability of male circumcision for prevention of HIV/AIDS in sub-Saharan Africa: a review. AIDS Behav 2007, 11:341-355.

102. Brito MO, Caso LM, Balbuena H, Bailey RC: Acceptability of male circumcision for the prevention of HIV/AIDS in the Dominican Republic. PLoS One 2009, 4:e7687, (6pages).

103. Madhivanan P, Krupp K, Chandrasekaran V, Karat SC, Reingold AL, Klausner JD: Acceptability of male circumcision among mothers with male children in Mysore, India. AIDS 2008, 22:983-988. 
104. Adler R, Ottaway S, Gould S: Circumcision: we have heard from the experts; now let's hear from the parents. Pediatrics 2001, 107: [http:// www.pediatrics.org/cgi/content/full/107/102/e120.]

105. Wang ML, Macklin EA, Tracy E, Nadel H, Catlin EA: Updated parental viewpoints on male neonatal circumcision in the United States. Clin Pediatr (Phila) 2010, 49:130-136.

106. Xu B, Goldman H: Newborn circumcision in Victoria, Australia: reasons and parental attitudes. ANZ J Surg 2008, 78:1019-1022.

107. Ahaghotu C, Okafor H, Igiehon E, Gray E: Psychosocial factors influence parental decision for circumcision in pediatric males of African American decent. J Natl Med Assoc 2009, 101:325-330.

108. Gust DA, Kretsinger K, Pals SL, Gaul ZJ, Hefflefinger JD, Begley EB, Chen RT Kilmarx PH: Male circumcision as an HIV prevention intervention in the U.S.: influence of health care providers and potential for risk compensation. Prev Med 2011, 52:270-273.

109. Westercamp M, Agot KE, Ndinya-Achola J, Bailey RC: Circumcision preference among women and uncircumcised men prior to scale-up of male circumcision for HIV prevention in Kisumu, Kenya. AIDS Care 2012, 24:157-166.

110. Madhivanan P, Krupp K, Kulkarni V, Kulkarni S, Klausner JD: Acceptability of male circumcision for HIV prevention among high-risk men in Pune, India. Sex Transm Dis 2011, 38:571.

111. Herman-Roloff A, Otieno N, Agot K, Ndinya-Achola JO, Bailey RC: Acceptability of medical male circumcision among uncircumcised men in Kenya one year after the launch of the national male circumcision program. PLoS One 2010, 6:e19814, (6pages)

112. Tieu HV, Phanuphak N, Ananworanich J, Vatanparast R, Jadwattanaku LT, Pharachetsakul N, Mingkwanrungrueng P, Buajoom R, Teeratakulpisarn S, Teeratakulpisarn N, Methajittiphun P, Hammer SM, Ann Chiasson M, Phanuphak P: Acceptability of male circumcision for the prevention of HIV among high-risk heterosexual men in Thailand. Sex Transm Dis 2010, 37:352-355.

113. Sullivan SG, Ma W, Duan S, Li F, Wu Z, Detels R: Attitudes towards circumcision among Chinese men. J Acquir Immune Defic Syndr 2009, 50:238-240.

114. Feng $N$, Lü F, Zeng G, Nan L, Wang XY, Xu P, Zhang JX, Zhang SE: [Acceptability and related factors on male circumcision among young men with Yi ethnicity in one county of Sichuan province] (In Chinese). Zhonghua Liu Xing Bing Xue Za Zhi 2010, 31:281-285.

115. Hao L, Xu L, Jian C, Xiao-Bo Y, Jun-Jun J, Wei D: [Acceptability of male circumcision among male miners in Baise of Guangxi] (In Chinese). Zhongguo Yi Xue Ke Xue Yuan Xue Bao 2011, 33:313-317.

116. Wei C, Raymond HF, McFarland W, Buchbinder S, Fuchs JD: What is the potential impact of adult circumcision on the HIV epidemic among men who have sex with men in San Francisco? Sex Transm Dis 2010, 38:353-355.

117. McDaid LM, Weiss HA, Hart GJ: Circumcision among men who have sex with men in Scotland: limited potential for HIV prevention. Sex Transm Infect 2010, 86:404-406

118. Lau JT, Zhang J, Yan H, Lin C, Choi KC, Wang Z, Hao C, Huan X, Yang H: Acceptability of circumcision as a means of HIV prevention among men who have sex with men in China. AIDS Care 2011, 23:1472-1482

119. Millett GA, Flores SA, Marks G, Reed JB, Herbst JH: Circumcision status and risk of HIV and sexually transmitted infections among men who have sex with men: a meta-analysis. JAMA 2008, 300:1674-1684.

120. Kigozi G, Gray RH, Wawer MJ, Serwadda D, Makumbi F, Watya S, Nalugoda F, Kiwanuka N, Moulton LH, Chen MZ, Sewankambo NK, Wabwire-Mangen F, Bacon MC, Ridzon R, Opendi P, Sempijja V, Settuba A, Buwembo D, Kiggundu V, Anyokorit M, Nkale J, Kighoma N, Charvat B: The safety of adult male circumcision in HIV-infected and uninfected men in Rakai, Uganda. PLoS Med 2008, 5:e116, (8pages).

121. Barone MA, Ndede F, Li PS, Masson P, Awori Q, Okech J, Cherutich P, Muraguri N, Perchal P, Lee R, Kim HH, Goldstein M: The Shang Ring device for adult male circumcision: A proof of concept study in Kenya. J Acquir Immune Defic Syndr 2011, 57:e7-e12.

122. Russell CT, Chaseling J: Topical anaesthesia in neonatal circumcision: a study of 208 consecutive cases. Aust Fam Physician 1996, 25(suppl 1):30-34.

123. van Dijk M, de Boer JB, Koot $H$, Duivenvoorden HJ, Passchier J, Boowmeester N, Tibboel D: The association between physiological and behavioral pain measures in 0- to 3-year-old infants after major surgery. J Pain Symptom Mgt 2001, 22:600-609.

124. Bergqvist LL, Katz-Salamon M, Hertegård S, Anand KJ, Lagercrantz H: Mode of delivery modulates physiological and behavioral responses to neonatal pain. J Perinatol 2009, 29:44-50.

125. Sternberg WF, Scorr L, Smith LD, Ridgway CG, Stout M: Long-term effects of neonatal surgery on adulthood pain behavior. Pain 2005, 113:347-353.

126. Laprairie $J$, Murphy AZ: Neonatal injury alters adult pain sensitivity by increasing opioid tone in the periaqueductal gray. Front Behav Neurosci 2009, 3(article 31):1-11.

127. Taddio A, Stevens B, Craig K, Rastogi P, Bendavid S, Shennan A, Mulligan P, Koren G: Efficacy and safety of lidocaine-prilocaine cream for pain during circumcision. N Engl J Med 1997, 336:1197-1201.

128. Potetz L, Cubanski J, Neuman T: Medicare spending and financing. A primer. Helath Policy Alternatives Inc and The Henry J. Kaiser Family Foundation. 2011 [http://www.kff.org/medicare/upload/7731-03.pdf].

129. Leibowitz AA, Desmond K, Belin T: Determinants and policy implications of male circumcision in the United States. Am J Public Health 2009, 99:138-145.

130. Morris BJ, Bailis SA, Waskett JH, Wiswell TE, Halperin DT: Medicaid coverage of newborn circumcision: a health parity right of the poor. Am J Public Health 2009, 99:969-971.

131. Schoen EJ, Colby CJ, To TT: Cost analysis of neonatal circumcision in a large health maintenance organization. J Urol 2006, 175:1111-1115.

132. Morris BJ, Castellsague X, Bailis SA: Re: Cost analysis of neonatal circumcision in a large health maintenance organization. E. J. Schoen, C. J. Colby and T. T. To. J Urol, 175: 1111í1115, 2006. J Urol 2006, 176:2315-2316

133. Sansom SL, Prabhu VS, Hutchinson AB, An Q, Hall HI, Shrestha RK, Lasry A, Taylor AW: Cost-effectiveness of newborn circumcision in reducing lifetime HIV risk among U.S. males. PLoS One 2010, 5:8723.

134. Anderson J, Wilson D, Templeton DJ, Grulich A, Carter R, Kaldor J: Costeffectiveness of adult circumcision in a resource-rich setting for HIV prevention among men who have sex with men. J Infect Dis 2009, 200:1803-1812.

135. Central Intelligence Agency: Country Comparison: GDP - per capita (PPP). 2004, Retrieved from: https://www.cia.gov/library/publications/the-worldfactbook/rankorder/2004rank.html.

136. World Health Organization: CHOosing Interventions that are Cost Effective (WHOCHOICE). 2011, Retrieved from: http://www.who.int/choice/ en/.

137. Williams BG, Lloyd-Smith JO, Gouws E, Hankins C, Getz WM, Hargrove J, de Zoysa I, Dye C: The potential impact of male circumcision on HIV in SubSaharan Africa. PLoS Med 2006, 3(e262):1032-1040.

138. Gray RH, Li X, Kigozi G, Serwadda D, Nalugoda F, Watya S, Reynolds SJ, Wawer M: The impact of male circumcision on HIV incidence and cost per infection prevented: a stochastic simulation model from Rakai, Uganda. AIDS 2007, 21:845-850.

139. Galárraga O, Colchero MA, Wamai RG, Bertozzi SM: HIV prevention costeffectiveness: a systematic review. BMC Public Health 2009, 9(Suppl 1):\$5

140. Uthman OA, Popoola TA, Uthman MM, Aremu O: Economic evaluations of adult male circumcision for prevention of heterosexual acquisition of HIV in men in sub-Saharan Africa: a systematic review. PLOS One 2010, 5: e9628, (7pages).

141. Lissouba P, Taljaard D, Rech D, Doyle S, Shabangu D, Nhlapo C, OtchereDarko J, Mashigo T, Matson C, Lewis D, Billy S, Auvert B: A model for the roll-out of comprehensive adult male circumcision services in African low-income settings of high HIV incidence: the ANRS 12126 Bophelo Pele Project. PLoS Med 2010, 7:e1000309, (13pages).

142. Green LW, Travis JW, McAllister RG, Peterson KW, Vardanyan AN, Craig A Male circumcision and HIV prevention insufficient evidence and neglected external validity. Am J Prev Med 2010, 39:479-482.

143. Garenne M: Long-term population effects of male circumcision in generalized HIV epidemics in sub-Saharan Africa. Afr J AIDS Res 2008, 7:1-8.

144. Connolly C, Simbayi LC, Shanmugam R, Nqeketo A: Male circumcision and its relationship to HIV infection in South Africa: results of a national survey in 2002. S Afr Med J 2008, 98:789-794.

145. Bermudez DM, Canning DA, Liechty KW: Age and pro-inflammatory cytokine production: Wound-healing implications for scar-formation and the timing of genital surgery in boys. J Pediatr Urol 2011, 7:324-331. 
146. Fink KS, Carson CC, de Vellis RF: Adult circumcision outcomes study: Effect on erectile function, penile sensitivity, sexual activity and satisfaction. J Urol 2002, 167:2113-2116.

147. Masood S, Patel HRH, Himpson RC, Palmer JH, Mufti GR, Sheriff MKM: Penile sensitivity and sexual satisfaction after circumcision: are we informing men correctly? Urol Int 2005, 75:62-66.

148. Goicochea P, Sanchez J, Morales M, Celum C: Feasibility, acceptability and willingness to participate in a male circumcision trial for the prevention of HIV acquisition in men who have sex with men in the Andes. 5th IAS Conference on HIV Pathogenesis and Treatment 2009, Abstract\#TUPEC068.

149. Laumann EO, Maal CM, Zuckerman EW: Circumcision in the United States. Prevalence, prophyactic effects, and sexual practice. J Am Med Assoc 1997, 277:1052-1057.

150. Richters J, Smith AM, de Visser RO, Grulich AE, Rissel CE: Circumcision in Australia: prevalence and effects on sexual health. Int J STD AIDS 2006, 17:547-554.

151. Collins S, Upshaw J, Rutchik S, Ohannessian C, Ortenberg J, Albertsen P: Effects of circumcision on male sexual function: Debunking a myth? J Urol 2002, 167:2111-2112.

152. Ferris JA, Richters J, Pitts MK, Shelley JM, Simpson JM, Ryall R, Smith AMA: Circumcision in Australia: further evidence on its effects on sexual health and wellbeing. Aust N Z J Publ HIth 2010, 34:160-164.

153. Kigozi G, Watya S, Polis CB, Buwembo D, Kiggundu V, Wawer MJ, Serwadda D, Nalugoda F, Kiwanuka N, Bacon MC, Ssempijja V, Makumbi F, Gray $\mathrm{RH}$ : The effect of male circumcision on sexual satisfaction and function, results from a randomized trial of male circumcision for human immunodeficiency virus prevention, Rakai, Uganda. BJU Int 2008 , 101:65-70.

154. Aydur E, Gungor S, Ceyhan ST, Taiimaz L, Baser I: Effects of childhood circumcision age on adult male sexual functions. Int J Impot Res 2007 19:424-431.

155. Mao LM, Templeton DJ, Crawford J, Imrie J, Prestage GP, Grulich AE Donovan B, Kaldor JM, Kippax SC: Does circumcision make a difference to the sexual experience of gay men? Findings from the Health in Men (HIM) Cohort. J Sex Med 2008, 5:2557-2561.

156. Morris BJ, Waskett JH, Gray RH: Does sexual function survey in Denmark offer any support for circumcision having an adverse effect? Int $J$ Epidemiol 2012, 41:310-312

157. Frisch M, Lindholm M, Grønbeck M: Male circumcision and sexual function in men and women: a survey-based-cross-sectional study in Denmark. Int J Epidemiol 2011, 40:1367-1381.

158. Mehta SD, Gray RH, Auvert B, Moses S, Kigozi G, Taljaard D, Puren A, Agot K, Serwadda D, Parker CB, Wawer MJ, Bailey RC: Does sex in the early period after circumcision increase HIV-seroconversion risk? Pooled analysis of adult male circumcision clinical trials. AIDS 2009, 23:1557-1564.

159. Shelton JD: Masturbation: breaking the silence. Int Perspect Sex Reprod Health 2010, 36:157-158.

160. Okino BM, Yamamoto LG: Survey of Internet web sites on circumcision. Clin Pediatr (Phila) 2004, 43:667-669.

161. Masters WH, Johnson VE: Human Sexual Response Boston: Little Brown; 1966.

162. Bleustein CB, Fogarty JD, Eckholdt H, Arezzo JC, Melman A: Effect of neonatal circumcision on penile neurological sensation. Urology 2005, 65:773-777.

163. Schober JM, Meyer-Bahlburg HF, Dolezal C: Self-ratings of genital anatomy, sexual sensitivity and function in men using the 'SelfAssessment of Genital Anatomy and Sexual Function, Male' questionnaire. BJU Int 2009, 103:1096-1103.

164. Payne $K$, Thaler $L$, Kukkonen T, Carrier S, Binik Y: Sensation and sexual arousal in circumcised and uncircumcised men. J Sex Med 2007 4:667-674.

165. Son H, Song SH, Kim SW, Paick JS: Self-reported premature ejaculation prevalence and characteristics in Korean young males: communitybased data from an Internet survey. J Androl 2010, 31:540-546.

166. Waldinger MD, Quinn P, Dilleen M, Mundayat $R$, Schweitzer DH, Boolell M: A multinational population survey of intravaginal ejaculation latency time. J Sex Med 2005, 2:492-497.

167. Waldinger MD, Mclntosh J, Schweitzer DH: A five-nation survey to assess the distribution of the intravaginal ejaculatory latency time among the general male population. J Sex Med 2009, 6:2888-2895.
168. Senol MG, Sen B, Karademir K, Sen H, Saraçoğlu M: The effect of male circumcision on pudendal evoked potentials and sexual satisfaction. Acta Neurol Belg 2008, 108:90-93.

169. Senkul T, Iseri C, Sen B, Karademir K, Saracoglu F, Erden D: Circumcision in adults: effect on sexual function. Urology 2004, 63:155-158.

170. Williamson ML, Williamson PS: Women's preferences for penile circumcision in sexual partners. J Sex Educ Ther 1988, 14:8-12.

171. Wildman RW, Wildman RW II, Brown A, Trice C: Note on males' and females' preferences for opposite sex body parts, bust sizes, and bustrevealing clothing. Psychol Rep 1976, 38:485-486.

172. Kigozi G, Lukabwe I, Kagaayi J, Wawer MJ, Nantume B, Kigozi G, Nalugoda F, Kiwanuka N, Wabwire-Mangen F, Serwadda D, Ridzon R, Buwembo D, Nabukenya D, Watya S, Lutalo T, Nkale J, Gray RH: Sexual satisfaction of women partners of circumcised men in a randomized trial of male circumcision in Rakai, Uganda. BJU Int 2009, 104:1698-1701.

173. Cortés-González JR, Arratia-Maqueo JA, Gómez-Guerra LS: [Does circumcision has an effect on female's perception of sexual satisfaction?] (In Spanish). Rev Invest Clin 2008, 60:227-230.

174. Sharlip I: Circumcision and the risk of HIV transmission in Africa. J Sex Med 2008, 5:2481-2484

175. Schlosberger NM, Turner RA, Irwin CE Jr: Early adolescent knowledge and attitudes about circumcision: methods and implications for research. $J$ Adolescent HIth 1992, 13:293-297.

176. Stenram A, Malmfors G, Okmian L: Circumcision for phimosis: a follow-up study. Scand J Urol Nephrol 1986, 20:89-92.

177. Sen R, Wagner W: History, emotions and hetero-referential representations in inter-group conflict: the example of Hindu-Muslim relations in India. Paper Soc Representations 2005, 14:2.1-2.23.

178. Chandhiok N, Gangakhedkar RR: The new evidence on male circumcision: an Indian perspective. Reprod Health Matters 2007, 15:53-56.

179. Mattson CL, Campbell RT, Bailey RC, Agot K, Ndinya-Achola JO, Moses S: Risk compensation is not associated with male circumcision in Kisumu, Kenya: a multi-faceted assessment of men enrolled in a randomized controlled trial. PLoS One 2008, 3:e2443, (9pages).

180. Peltzer K, Simbayi L, Banyini M, Kekana Q: HIV risk reduction intervention among medically circumcised young men in South Africa: a randomized controlled trial. Int J Behav Med 2011.

181. Kalichman SC: Neonatal circumcision for HIV prevention: cost, culture, and behavioral considerations. PLoS Med 2010, 7:e1000219.

182. de la Hunt MN: Paediatric day care surgery: a hidden burden for primary care? Ann R Coll Surg Engl 1999, 81:179-182.

183. Rennie S, Muula AS, Westreich D: Male circumcision and HIV prevention: ethical, medical and public health tradeoffs in low-income countries. $J$ Med Ethics 2007, 33:357-361.

184. Benatar M, Benatar D: Between prophylaxis and child abuse: the ethics of neonatal male circumcision. Am J Bioeth 2003, 3:35-48.

185. Vawda YA, Maqutu LN: Neonatal circumcision - violation of children's rights or public health necessity? S Afr J Bioethics Law 2011, 4:36-42.

186. UNAIDS/WHO/SACEMA Expert Group on Modelling the Impact and Cost of Male Circumcision for HIV Prevention: Male circumcision for HIV prevention in high HIV prevalence settings: what can mathematical modelling contribute to informed decision making? PLoS Med 2009, 6 e1000109

187. Bateman C: Male circumcision roll-out certain - now for 'the how'. S Afr Med J 2010, 100:84-86.

\section{Pre-publication history}

The pre-publication history for this paper can be accessed here:

http://www.biomedcentral.com/1471-2431/12/20/prepub

doi:10.1186/1471-2431-12-20

Cite this article as: Morris et al:: A 'snip' in time: what is the best age to circumcise? BMC Pediatrics 2012 12:20. 